\title{
Characterization and biological properties of Pouteria torta extracts: a preliminary study
}

\author{
J.P. Perfeito ${ }^{1}$, M.L. Santos ${ }^{2}$, K.S.E. López ${ }^{1}$, J.E. Paula ${ }^{3}$ D. Silveira ${ }^{1 *}$ \\ ${ }^{1}$ Faculdade de Ciências da Saúde, Universidade de Brasília, Campus Darcy Ribeiro, Asa Norte, 70910-900, \\ Brasília, DF, Brasil, \\ ${ }^{2}$ Laboratório de Isolamento e Transformação de Moléculas Orgânicas, Instituto de Química, Universidade de \\ Brasília, Campus Darcy Ribeiro, Asa Norte, Brasília, 70904-970, DF, Brasil, \\ ${ }^{3}$ Departamento de Botânica, Instituto de Biologia, Universidade de Brasília, Campus Darcy Ribeiro, Asa Norte, \\ Brasília, 70910-970, DF, Brasil
}

\begin{abstract}
Hexane, ethanol and aqueous extracts and fractions from leaves of Pouteria torta (Mart.) Radlk (Sapotaceae), a perennial tree, widespread in the Brazilian Cerrado, were tested for cytotoxicity with the Artemia salina toxicity model. Only the aqueous crude extract and the MeCN: $\mathrm{CHCl}_{3}$ fraction of the ethanol extract presented toxicity $(0.28 \mathrm{mg} / \mathrm{mL}$ and $0.27 \mathrm{mg} / \mathrm{mL}$, respectively). Lupeol acetate was isolated from the hexane extract. It is the first report of lupeol acetate from the genus Pouteria.
\end{abstract}

Keywords: Pouteria torta, Artemia salina, Sapotaceae, lupeol acetate.

\section{INTRODUCTION}

Pouteria torta (Mart.) Radlk (Sapotaceae), popularly called "guapeva”, “curiola”, “acá ferro", "abiu do cerrado", and "grão de galo", is a perennial tree widespread in the Brazilian Cerrado, but can also be found from the Amazon region to the State of Bahia. People living in Cerrado eat the yellow fruits and use the tree bark as an antidysenteric medicine.

In previous studies about the chemical composition of the hexane and dichloromethane extracts from the flowers and fruits of P. torta, fat acid mixtures, poliisoprenoid compounds, hydrocarbon mixtures, and triterpenes were obtained (David, 1993).

Recently, it was reported that the methanol extract of $P$. torta leaves showed antimicrobial activity against Cladosporium sphaerospermum, Staphylococcus aureus, Escherichia coli, Bacillus cereus and Pseudomonas aeruginosa (Alves et al., 2000).

As shown above, despite the therapeutic properties attributed to $P$. torta, the plant has not been well investigated for its biological activities, and few data can be found regarding to the chemical composition of this species. The main purpose of this study was to evaluate the potential antitumor properties of the hexane, ethanol, and aqueous extracts and fractions from the leaves of $P$. torta by using the Artemia salina toxicity model, as a prescreening procedure, and the structural characterization of one of the components from the hexane crude extract.

\section{MATERIAL AND METHODS}

\section{General procedures}

*E-mail: damaris@unb.br. Tel. +55-61-3402134
Column chromatography was carried out using silica gel Merck 60 (0.063- $0.200 \mathrm{~mm})$. Analytical thin layer chromatography was performed on precoated ALUGRAM Sil G Machery-Nagel silica gel (60/0.2 mm) plates using UV light, anisaldehyde $/ \mathrm{H}_{2} \mathrm{SO}_{4}$, and vanillin/ $\mathrm{H}_{2} \mathrm{SO}_{4}$ reagents (Wagner; Bladt, 1996) to visualize the spots. ${ }^{13} \mathrm{C}$-NMR spectra were recorded on a Mercury plus spectrometer, Varian (7.05 T), operating at $75 \mathrm{MHz}$ and performed in $\mathrm{CDCl}_{3} / \mathrm{TMS} .{ }^{13} \mathrm{C}$ chemical shifts $(\delta)$ are reported in parts per million (ppm) relative to TMS.

\section{Plant material}

Leaves of $P$. torta were collected on the campus of the Universidade de Brasília in July, 2003. An exsiccate is deposited in the Herbarium of the Universidade de Brasília (UB) and the species was identified by Professor J. E. de Paula (voucher number JElias de Paula 3674).

\section{Extraction}

The plant material was dried at room temperature and powdered in a knife mill. Part of this material (918 g) was macerated at room temperature for seven days (repeated for three times), first with hexane, followed by ethanol. After filtration, the solvents were removed under reduced pressure, at temperatures below $40^{\circ} \mathrm{C}$.

The aqueous extract, from $400 \mathrm{~g}$ of the powdered material, was obtained by infusion, using distillated water (3 L). After filtration, the water was removed by lyophilization technique to yield $44 \mathrm{~g}$ (11\%) of crude aqueous extract. 
Table 1. Toxicity screening of Pouteria torta crude extracts and fractions against Artemia salina larvae.

\begin{tabular}{lccc}
\hline \multicolumn{1}{c}{ Samples } & $\mathrm{LD}_{50}(\mathrm{ppm})$ & $\mathrm{LD}_{50}(\mathrm{mg} / \mathrm{mL})$ & Confidence interval $95 \%$ \\
\hline Hexane crude extract & $>1000$ & $>1.0$ & - \\
Ethanol crude extract & $>1000$ & $>1.0$ & - \\
Aqueous crude extract & 280 & 0.28 & $154-498$ \\
MeCN:CHCl $_{3}$ fraction & 270 & 0.27 & $112-427$ \\
Aqueous fr. fraction & $>1000$ & $>1.0$ & - \\
Hexane fr. fraction & $>1000$ & $>1.0$ & - \\
Lupeol acetate (Pt1) & $>200$ & $>0.2$ & - \\
Potassium dichromate & 80 & 0.08 & $53-85$ \\
\hline
\end{tabular}

Finally, the ethanol extract was partitioned using Hexane: $\mathrm{CHCl}_{3}$ : $\mathrm{CH}_{3} \mathrm{CN}$ : $\mathrm{H}_{2} \mathrm{O}$ (2:1: 3.4:1) (Duarte et al., 2000) yielding three fractions. The yields of crude extracts and fractions are presented in Figure 1.

\section{Brine shrimp lethality test (BST)}

Table 2. Comparison of Pt1 ${ }^{13} \mathrm{C}$ NMR chemical shifts $\left(\mathrm{CDCl}_{3}\right.$ $75 \mathrm{MHz}$ ) with literature data of the lupeol acetate.

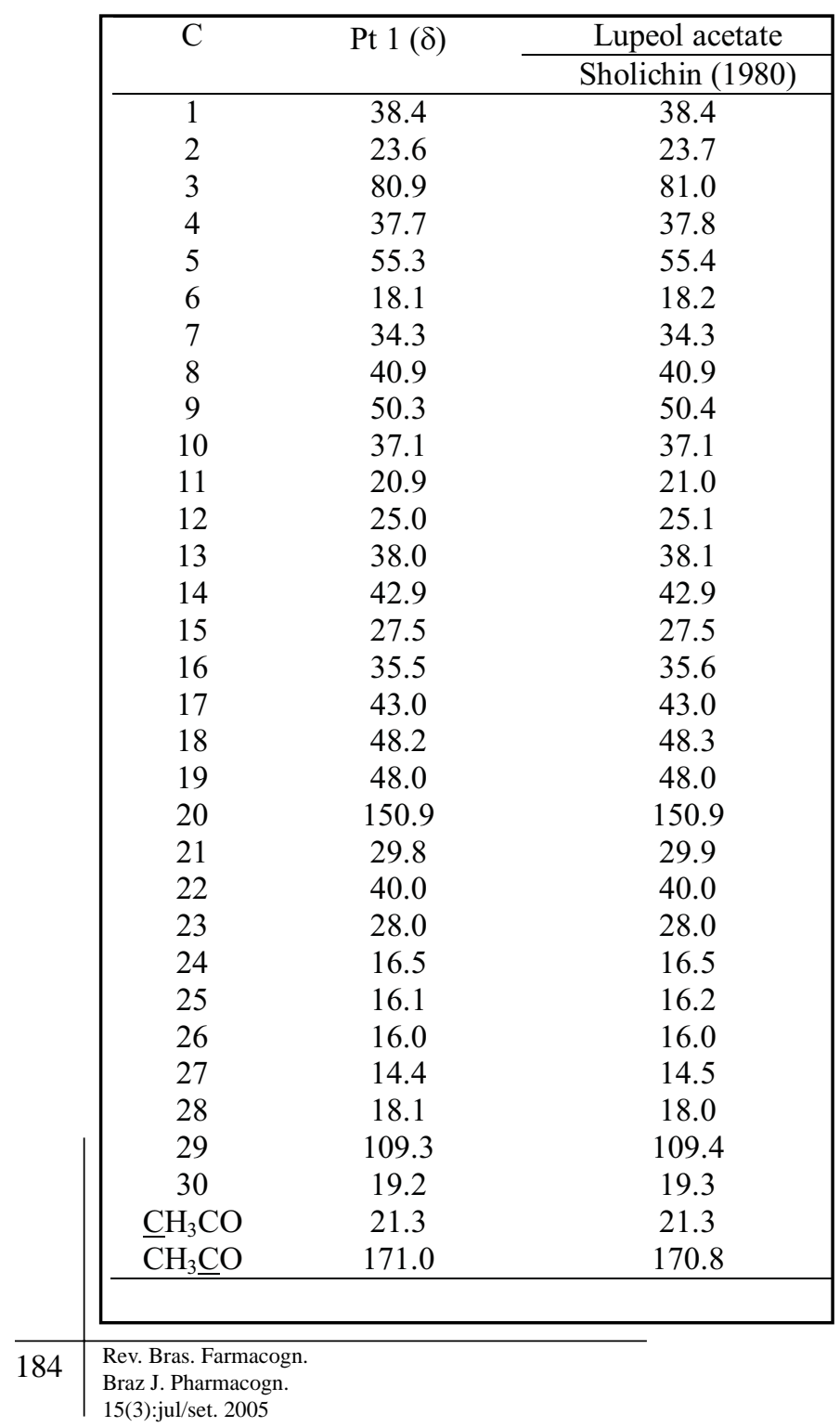

All fractions were tested for brine shrimp lethality. The assay was performed basically according to the simplified Meyer's method (Meyer et al., 1982). Briefly, brine shrimp, Artemia salina L. encysted eggs (Maramar) were incubated in artificial seawater at $28^{\circ} \mathrm{C}$. Samples were dissolved in $200 \mu \mathrm{L}$ of DMSO plus $20 \mathrm{~mL}$ of artificial seawater. Serial dilutions (triplicate) were prepared in the same solution. Metanauplii (10 units) was added to each set of tubes containing samples and the cultures further incubated for $24 \mathrm{~h}$. Controls containing DMSO were included on each set of experiments. Potassium dichromate was used as reference standard. $\mathrm{LD}_{50}$ (after $24 \mathrm{~h}$ ) were calculated by Probit analysis.

\section{Chemical constituents of hexane extract}

Hexane extract (5 g) was chromatographed over silica gel, by using hexane: ethyl acetate: methanol gradient. After analysis by TLC, the obtained 24 fractions were gathered in 8 groups. Group 1 (93 mg) furnished a hydrocarbon mixture. Group 3 (50 $\mathrm{mg}$ ) was extracted by acetone, furnishing $25 \mathrm{mg}$ of amorphous white solid characterized as long chain esters mixture. Groups 5, 6, 7 and 8 (503 mg) were extracted by acetone: methanol (1:1) furnishing $82 \mathrm{mg}(1.2 \%)$ of a white amorphous solid (Pt1). Groups 2 and 4 were found to be very complex mixtures and were not studied at this time.

\section{RESULTS AND DISCUSSION}

The study of the leaves of Pouteria torta allowed to obtain three crude extracts and by the tri-phase<smiles>C=C(C)C1CCC2(C)CCC3(C)C(CCC4C5(C)CCC(OC(C)=O)C(C)(C)C5CCC43C)C12</smiles> 


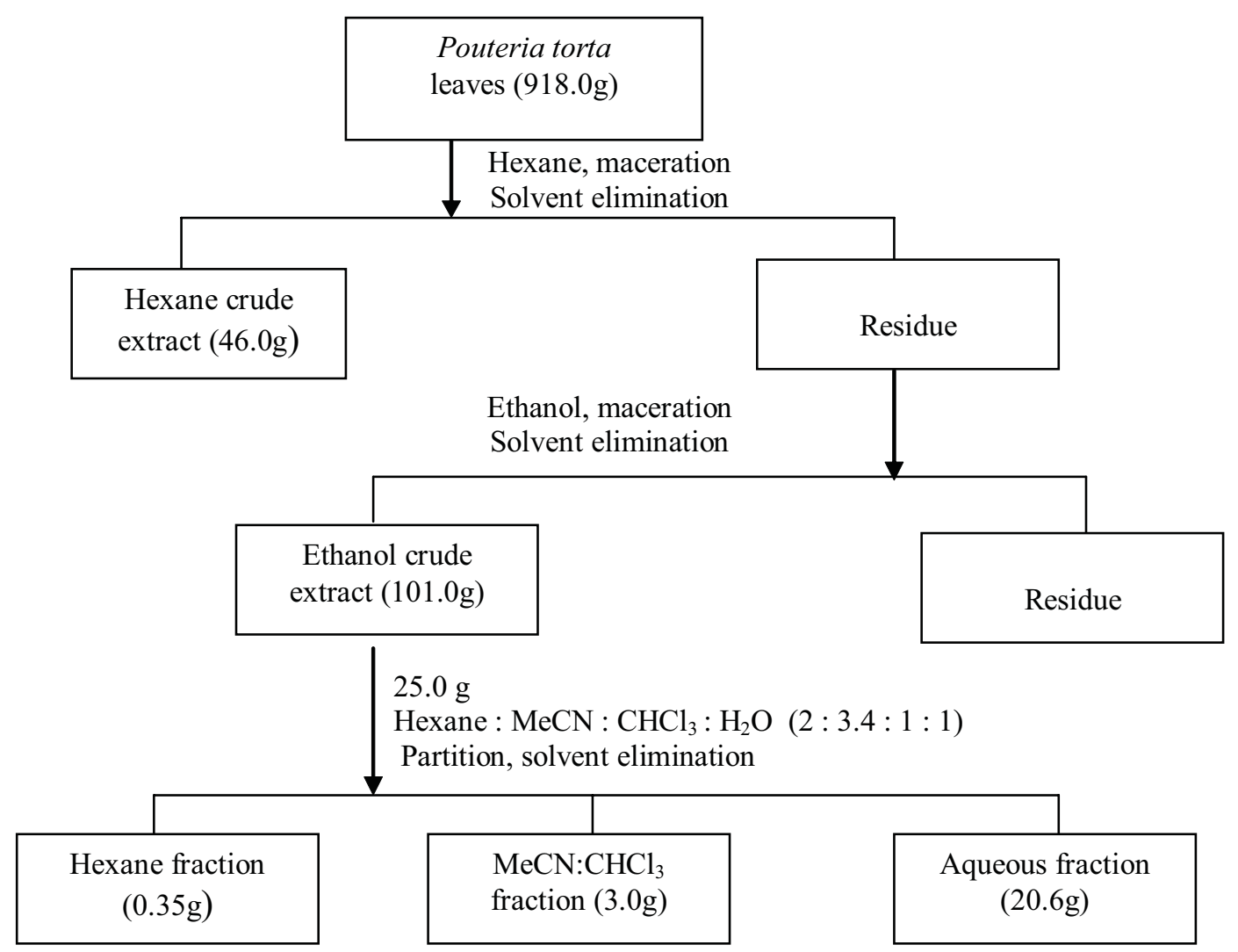

Figure 1. Crude extracts and fractions from Pouteria torta leaves

partition, we could separate the ethanol extract in three fractions with different polarity.

The chromatographic separation of the hexane extract of $P$. torta on silica gel column afforded Pt1. The ${ }^{13} \mathrm{C}$ NMR spectrum of Pt1 showed signals which led to its identification as lupeol acetate by comparison of NMR chemical shifts found at the literature data (Sholichin et al., 1980; Freire et al., 2002). Herein, we point out the fact that this is the first report of lupeol acetate in Pouteria species.

BST results are presented at Table 1 . In the toxicity evaluation of plant extracts by brine shrimp bioassay, a $\mathrm{LD}_{50}$ value lower than $1 \mathrm{mg} / \mathrm{mL}$ is considered bioactive (Meyer et al. 1982). In our experiments, we have used Meyer classification to the crude extracts and fractions, but we assume pure compounds toxic, when the $\mathrm{LD}_{50}$ value is lower to $0.2 \mathrm{mg} / \mathrm{mL}$. Based on this classification, aqueous crude extract and acetonitrile: chloroform fraction were considered toxic to Artemia salina larvae $(0.28 \mathrm{mg} / \mathrm{mL}$ and $0.27 \mathrm{mg} / \mathrm{mL}$, respectively), and lupeol acetate was considered non-toxic. Taking into account the good correlation between the toxicity on Artemia salina with that on tumor cell lines (e.g, KB, P388, L5178Y and L1210) (De Rosa et al., 1994), as well with several others assays such as trypanocidal (Zani et al., 1995) and phototoxicity (Ojala et al., 1999), besides to seeking compounds for protective activity against active oxygen species (AOS)-related damage (Mathews, 1995), further studies on Pouteria torta will be carried out to better define the spectrum of its biological activity and to understand the chemical composition of its extracts.

\section{ACKNOWLEDGEMENTS}

Financial support from CNPq, FINEP (Process CT-INFRA 970/2001), and FINATEC. The authors are indebted with to Professor Dr. Inês Sabioni Resck, Universidade de Brasilia, for the ${ }^{1} \mathrm{H}$ and ${ }^{13} \mathrm{C}(300 \mathrm{MHz})$ NMR spectra data.

\section{REFERENCES}

Alves TMA, Silva AF, Brandão M, Grandi TSM, Smânia EF, Smânia Jr A, Zani CL 2000. Biological screening of brazilian medicinal plants. Mem I Oswaldo Cruz 95: 367-373.

David V 1993. Aplicação de técnicas cromatográficas na separação e determinação de triterpenos $e$ hidrocarbonetos presentes nas flores, frutos $e$ xilopódio de Pouteria torta. São Carlos, 97p. Dissertação de Mestrado - Programa de Pós- 
graduação em Química, Universidade Federal de São Carlos.

De Rosa S, De Giulio A, Iodice C 1994. Biological effects of prenylated hydroquinones: structure-activity relationship studies in antimicrobial, brine-shrimp, and fish letality assays. $J$ Nat Prod 57: 1711-1716.

Duarte DS, Dolabela MF, Salas CE, Raslan DS, Oliveira AB, Nenninger A, Wiedemann B, Wagner H, Lombardi J, Lopes MTP 2000. Chemical characterization and biological activity of Macfadyena unguis-cati (Bignoniaceae). J Pharm Pharmacol 52: 347-352.

Freire MFI, Carvalho MG, Berbara RLL, Freire RB 2002. Atividade antimicrobiana de acetato de lupeol isolado de Vernonia scorpioides (Lam.) Pers., Asteraceae. Rev Bras Farm 83: 83-87.

Mathews RS 1995. Artemia salina as a test organism for measuring superoxide-mediated toxicity. Free Radical Bio Med 18: 919-22.

Meyer BN, Ferrigni NR, Putnan JE, Jacobsen LB, Nichols DE, McLaughlin JL 1982. Brine shrimp - a convenient general bioassay for active-plant constituents Planta Med 45: 31-33.

Ojala T, Vuorela P, Kiviranta J, Vuorela H, Hiltunen R 1999. A bioassay using Artemia salina for detecting phototoxicity of plant coumarins. Planta Med 65: 715-718.

Sholichin M, Yamasaki K, Kasai R, Tanaka O 1980. 13C Nuclear magnetic ressonance of lupane-type triterpenes 1980. Lupeol, betulinic acid. Chem Pharm Bull 28: 1006-1008.

Wagner H, Bladt S 1996. Plant drug analysis. 2.ed. Hong Kong: Springer-Verlag.

Zani CL, Chaves PPG, Queiroz R, Mendes NM, Oliveira AB, Cardoso JE, Anjos AMG, Grandi TS 1995. Brine shrimp lethality assay as a prescreening system for anti-Trypanosoma cruzi activity. Phytomedicine 2: 47-50. 